\title{
Cooperative efforts contained spread of Pierce's disease and found genetic resistance
}

by George Bruening, Bruce C. Kirkpatrick, Thomas Esser and Robert K. Webster

An outbreak of Pierce's disease of grapevine in the Temecula Valley in the late 1990s was one in a decades-long series of sporadic appearances of this infection in California. However, the new outbreak was qualitatively different because of the rapidity with which it spread in the vineyard and its appearance almost simultaneously at distant locations. The causative agent of Pierce's disease is the bacterium Xylella fastidiosa, and the distinct characteristics of the Temecula Valley outbreak were traced to the establishment of a new insect vector in California, the glassy-winged sharpshooter. Intensive and collaborative efforts among government agencies, industry and research institutions over 15 years have successfully contained the disease, and given scientists time to discover promising long-term potential solutions through genetic resistance.

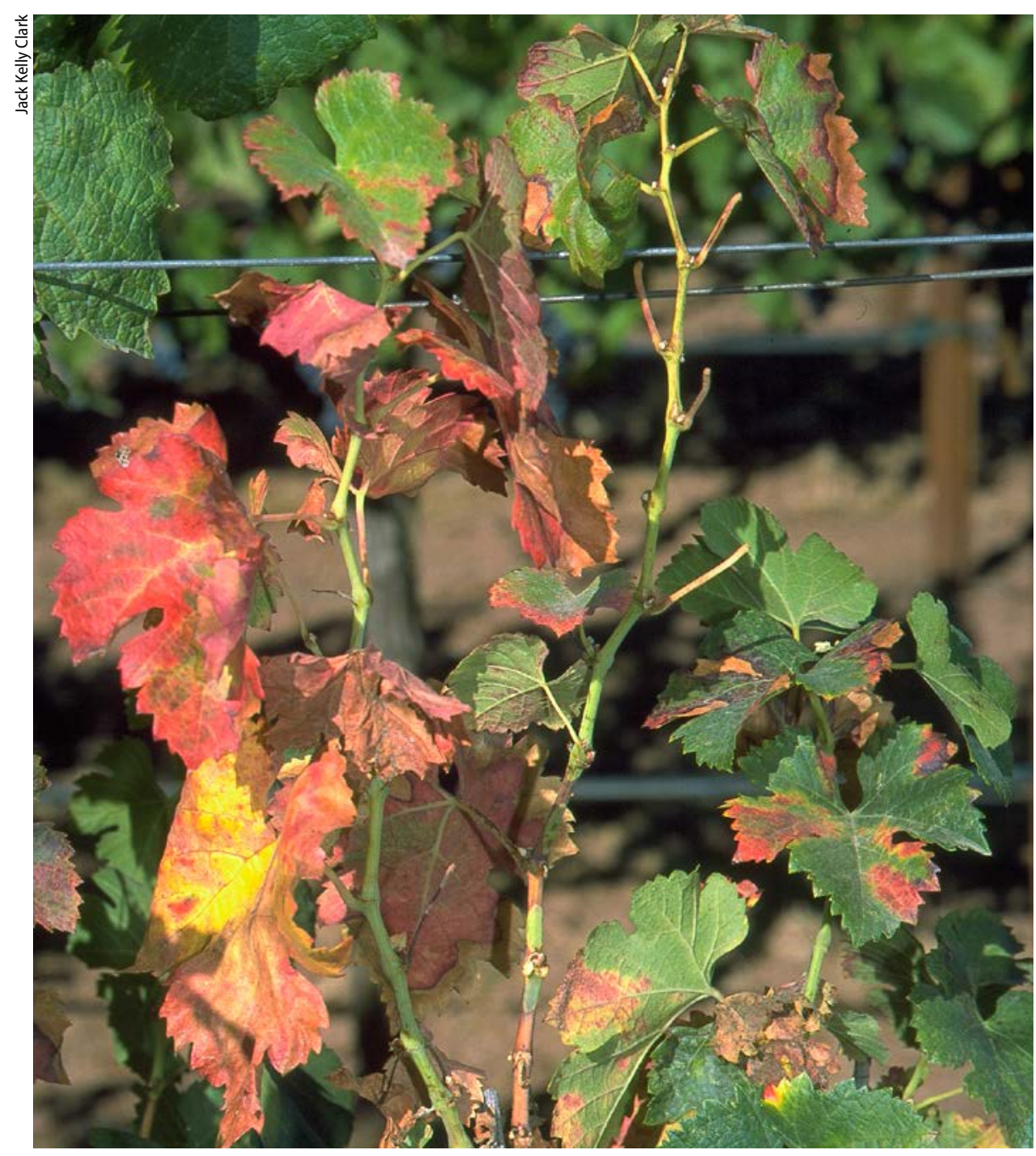

PD symptoms on a red grape variety, showing progressive foliage discoloration, irregular bark maturity and petioles without leaf blades. The Temecula Valley PD outbreak in 1999 triggered an emergency response to save the wine and grape industries.

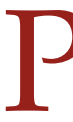
ierce's disease (PD) was not new to California in 1999, when its characteristic scorching symptoms suddenly and severely devastated several hundred acres of grapevines in the Temecula Valley, affecting a quarter of the region's vineyards. In the early 1880s, PD, then referred to as Anaheim disease, decimated 30,000 acres of vines near Anaheim and Pomona. Newton B. Pierce, a special agent of the U.S. Secretary of Agriculture, responded to this event as the first professional plant pathologist in California. He skillfully eliminated explanations other than disease but was not able to identify the causative agent. In the late 1880s, the disease damaged vineyards in Napa County, and there were severe outbreaks in Southern California in the 1930s and 1940s. Between 1994 and 2000, grapevines on over 1,000 acres in Northern California were affected, resulting in \$30 million in damage (Webster and Nation 2000).

The causative agent of PD was long thought to be a virus. The disease actually is caused by a strain of the bacterium Xylella fastidiosa (Davis et al. 1978). Strains of this bacterium also inflict damage on many other plant species, including almond, citrus, elm, maple, oak, oleander, stone fruit and sycamore. The 1999 outbreak in the Temecula Valley was unique, alarming and characterized by rapid and long-distance spread of PD in the vineyard, resulting from the establishment of a new vector in California, the glassywinged sharpshooter (GWSS; Homalodisca vitripennis). Further spread of GWSS would place at risk California's $\$ 3$ billion grape crop, $\$ 60$ billion in associated activity, and $\$ 3$ billion in fruit, nut and ornamental crops.

\section{Epidemiology of PD}

$X$. fastidiosa is transmitted in the field by xylem-feeding insects, especially

Online: http://californiaagriculture.ucanr.edu/ landingpage.cfm?article=ca.v068n04p134\&fulltext=yes doi: 10.3733/ca.v068n04p134 
sharpshooters (family Cicadellidae, subfamily Cicadellinae) and related insects such as spittlebugs (family Cercopidae) (Hopkins and Purcell 2002). Insect vectors acquire $X$. fastidiosa from infected plants; some plants are much more effective sources of the bacterium than others, depending on vector feeding preferences and patterns of $X$. fastidiosa accumulation and spread in the plant (Purcell and Saunders 1999). Ingested X. fastidiosa attaches to the sharpshooter's mouthparts, where it multiplies. Transmission to healthy plants occurs when the infected vector feeds and egests the bacterium into the plant's xylem. Plant symptoms, if any, appear weeks to months later. All nymphal stages of the sharpshooter can acquire $X$. fastidiosa, but nymphs lose the bacterium when they molt, because the mouth lining is shed during molting. If the sharpshooter acquires $X$. fastidiosa as an adult, it remains infective for the remainder of its life (Hopkins and Purcell 2002; Purcell and Finley 1979).

PD is most prevalent in grape-growing regions of the Southern U.S. states, Mexico and Central America, in areas that have mild winter temperatures. Research has shown that Vitis vinifera vines experimentally infected with $X$. fastidiosa will become pathogen-free if the vines are subjected to cold temperatures (Feil and Purcell 2001; Lieth et al. 2011). This cold curing phenomenon likely accounts for the lack of PD in viticultural regions such as New York, Oregon, Washington and higher-elevation vineyards in California, where vines experience cold winter temperatures. A recent model based on cold curing data by UC Davis professor Johan Lieth showed good predictive correlations between winter temperatures and the presence or absence of PD in viticultural regions in California (Lieth et al. 2011). Global warming is expected to alter crop geographical distributions (Weare 2009) and could reduce the areas currently subject to cold curing. Where winter temperatures have warmed in the Southeastern states, PD distribution has increased (Anas et al. 2008).

All cultivars of European grapevine, $V$. vinifera, are susceptible to $X$. fastidiosa infection. While most varieties eventually die from the infection, some varieties are more susceptible and succumb more quickly than others (Hopkins and Purcell 2002). Muscadine varieties (V. rotundifolia) and certain Vitis hybrids, especially those that are endemic to North America, such as $V$. labrusca X $V$. vinifera (Concord grape), support only very low $X$. fastidiosa titers, which do not affect fruit quality or kill the vine.

The incidence and severity of PD in California vineyards have been cyclic since the first record of PD in Anaheim and Pomona in the early 1880s. A PD epidemic occurred from 1933 to 1940 in the Central Valley, where diseased vineyards were often located next to weedy alfalfa fields, which were breeding sites for green (Draeculacephala minerva) and red-headed (Xyphon fulgida) sharpshooters (Hopkins and Purcell 2002). The blue-green sharpshooter (BGSS; Graphocephala atropunctata), a very efficient vector of PD, was largely responsible for the severe outbreaks of $\mathrm{PD}$ that have occurred in the coastal regions of Northern and Southern California and in the interior areas of Napa and Sonoma counties (Redak et al. 2004; Webster and Nation 2000).

None of these sharpshooters is a strong flyer, so the PD infections they cause are typically limited to an area of a few hundred meters from their overwintering sites, which for the BGSS are weedy riparian areas and ornamental landscapes. Vineyards can be protected by treating them with insecticides in the spring in response to BGSS counts in yellow sticky panel traps (Varela et al. 2001). When the emerging shoots are short, BGSSvectored $X$. fastidiosa can reach the permanent woody tissues of the vines and cause PD that persists and kills the vines. Inoculation of the green tips of longer canes later in the season tends to not result in systemic disease, since the infected portions of the vines are pruned off (Feil et al. 2003).

\section{The glassy-winged sharpshooter}

GWSS probably entered Southern California on imported plant material in the late 1980 s or early 1990s. While GWSS is not considered to be an



GWSS adults caught in a yellow sticky trap. In areas infested with GWSS, trap counts indicate when insecticides should be applied to citrus groves located near vineyards.

economically important pest of grapevines in its own right (Andersen et al. 2003), its establishment greatly increased the incidence and severity of PD in the viticultural regions of Southern California and the lower San Joaquin Valley. To date, GWSS has not become permanently established north of Fresno County, although incipient infestations have occurred sporadically and have been successfully eradicated thus far (CDFA 2013).

The epidemiology of PD transmitted by GWSS differs considerably from the epidemiology of PD spread by the BGSS and other native sharpshooters. GWSS, surprisingly, is a less efficient vector of

GWSS flies farther than other sharpshooters, has a polyphagous diet and can spread PD vine to vine. It initiates infections on a nearly yearround basis. 
$X$. fastidiosa than native California sharpshooters (Daugherty and Almeida 2009). However, GWSS is a highly polyphagous insect, feeding on a variety of plants to fulfill its nutritional requirements (Varela et al. 2001). It also flies much greater distances than the native sharpshooters. The severe PD losses that occurred in the Temecula region in the late 1990s and early 2000s often occurred in vineyards located adjacent to citrus orchards, which are preferred feeding and breeding hosts of GWSS. PD transmitted by GWSS can rapidly encompass an entire vineyard, and significant PD losses occurred in vineyards located a mile or more from citrus orchards.

Unlike native PD vectors, GWSS can acquire and transmit $X$. fastidiosa from woody tissues such as 1- to 2-year-old lignified canes (Almeida and Purcell 2003; Almeida et al. 2005), and even spurs that remain when the dormant vines are pruned. Thus, GWSS spreads

See also: Jetter KM, Morse JG, Kabashima JN. 2014. The cost of the glassy-winged sharpshooter to California grape, citrus and nursery producers. Calif Agr 68(4): 161-167. http://california agriculture.ucanr.edu/ landingpage.cfm? article=ca.E.v068n04 p161\&fulltext=yes
$X$. fastidiosa on a nearly year-round basis and initiates chronic infections of vines. Extensive disease mapping done in the early stages of the Temecula epidemic showed that GWSS can spread X. fastidiosa vine to vine. Other PD vectors tend to introduce the bacterium from infected nongrapevine sources outside the vineyard rather than from chronically infected vines (Varela et al. 2001).

\section{Preventing spread of GWSS}

After the magnitude of the threat from the Temecula PD epidemic was realized, the California Department of Food and Agriculture (CDFA) put in place a successful four-pronged program: containment, detection, rapid response and outreach.

Containment. Within the infected areas, the CDFA promulgated regulations aimed at interdicting likely pathways of GWSS spread from infested areas of Southern California. This involved regulating shipments of general nursery stock, bulk grapes and (later) bulk citrus. The



During hot weather, PD causes leaves to turn brown, typically first at the leaf margins. New infestations are met with a rapid response and have been eradicated in Northern California counties.

regulations required inspection, treatment, monitoring and certification of shipments from infested areas. Enforcement of the regulations is coordinated by the CDFA and usually performed by the staff of county agricultural commissioners (CDFA 2001).

The certification program, established to ensure that shipments of nursery stock were free of GWSS, was effective but proved to be labor intensive, expensive and a significant burden to many growers (Redak and Bethke 2003). In response, concerted efforts were made to find a treatment that could be relied upon to minimize the risk of spreading GWSS on shipments of plant material from infested areas. While adult and nymphal GWSS were found to be fairly susceptible to insecticide treatments, the egg masses of the insect, embedded in the foliage of plants, were not (Grafton-Cardwell et al. 2003; Redak and Bethke 2003). Trials conducted by researchers at UC Riverside eventually identified two insecticides effective against all GWSS stages. Based on the trial results and beginning in 2008, the Nursery Stock Approved Treatment Protocol (Kabashima et al. 2011) became an optional substitute for the certification program.

In large grape production areas that were already infested with GWSS, such as portions of Kern, Riverside and Tulare counties, area-wide trapping and treatment programs for reducing GWSS numbers were implemented and evaluated. In these programs, coordinated insecticide treatments were applied primarily to citrus and, on occasion, to windbreaks, when trap counts revealed GWSS populations at or above damage thresholds (CDFA 2005). Similar programs were later implemented in other infested viticultural areas. Removal of diseased vines helped reduce the incidence and sources of disease in these areas.

Detection. In addition to the GWSS containment activities, annual detection surveys in agricultural and urban areas were begun to search for new GWSS infestations and verify that uninfested areas remained free of GWSS. Surveys rely primarily on sticky yellow panel traps deployed in areas deemed at risk of GWSS introduction. Trapping is conducted every year during the warm-weather months, with some locations being monitored year-round.

Rapid response. Discovery of one or more GWSS in a new area triggers rapid response activity by the CDFA, which consists of intensive visual survey and deployment of more traps to determine if a new infestation exists and, if so, where its boundaries lie. New infestations are treated with insecticides applied primarily to preferred host plants of GWSS to eradicate the infestation (CDFA 2013).

Outreach. Outreach plays an important role in GWSS containment and suppression efforts. Outreach activities, including meetings, mailings and media pieces prepared by CDFA, UC, counties and outside contractors, are aimed at the affected industries and the general public to inform them of the new pest threat in California and the new programs and activities being conducted to address it. These efforts have helped gain compliance with new shipping requirements and enlisted assistance from the public in finding new infestations and preventing further spread of GWSS.

Success of the current fourpronged program is evidenced by two 
observations: The GWSS-infested area in California this year is only slightly larger than the area infested in 2002 (fig. 1), and 17 infestations found outside this area to date have been eradicated. The success of the GWSS control program shows it can be a model for responding to other pest invasions. However, the potential remains for GWSS populations to flare up, as evidenced by increased trap counts, and spread to new areas or resistance to current control methods could develop, requiring that program measures continue and prompting recent initiation of studies on resistance management.

While insecticide treatments have proven critical to keeping GWSS populations low and preventing the spread and establishment of GWSS in new areas of California, biological control is also used as part of an integrated management approach. Biological control efforts began in the late 1990s, when explorations for natural enemies were conducted in the native range of GWSS (Triapitsyn et al. 1998). The Temecula PD outbreak stimulated additional searches for biological control agents, and testing, rearing, release and monitoring of natural enemies are now being conducted on an ongoing basis (CDFA 2001, 2013).

The natural enemies predominantly used against the sharpshooter are tiny mymarid wasps in the genus Gonatocerus, which lay their eggs inside the eggs of the sharpshooter. Approximately 2.4 million of these wasps have been released in California to date (CDFA 2013). These efforts have involved a collaborative response from CDFA (Larry Bezark, David Morgan, Charlie Pickett), UC Riverside (Ali Al-Wahibi, Mark Hoddle, Nick Irvin, Rodrigo Krugner, Joseph Morse, Leigh Pilkington, Serguei Triapitsyn) and USDA (Greg Simmons).

\section{Genetic approaches to combating PD}

Genetic resistance is generally regarded as the most reliable control measure for a readily transmitted plant disease. Although there is apparent variation in the susceptibility of European grapevine ( $V$. vinifera) varieties to $X$. fastidiosa, all succumb to PD (Hopkins and Purcell 2002). The research group of Andrew Walker at UC Davis discovered both apparently single-gene and multiplegene resistance in other Vitis species collected in the Southern U.S. states and northern Mexico (Walker and Riaz 2012). Progeny of interspecific (i.e., interspecies) crosses and backcrosses to $V$. vinifera were evaluated for a spectrum of horticultural and quality traits in addition to resistance to X. fastidiosa (Viana et al. 2011). Aggressive vine training, which forced flowering of 2-year-old seedlings, and application of DNA marker technology generated progeny of the fourth backcross, expected to be genetically $97 \%$ V. vinifera, in only 10 years. Test-size lots of wine have been made from grapes of previous generations and currently are being made from fourth backcross generation selections. Release of PD-resistant varieties with a range of wine styles is anticipated (Walker and Tenscher 2012). The breeding program continues.

Efforts in other laboratories have transferred specific genes from nongrapevine sources, referred to as transgenes, into $V$. vinifera. The advantage of the transgenic approach is that it greatly increases the number of sources of resistance beyond what is available in conventional breeding. Ten years ago, only a few sketchy notions were available on how to create

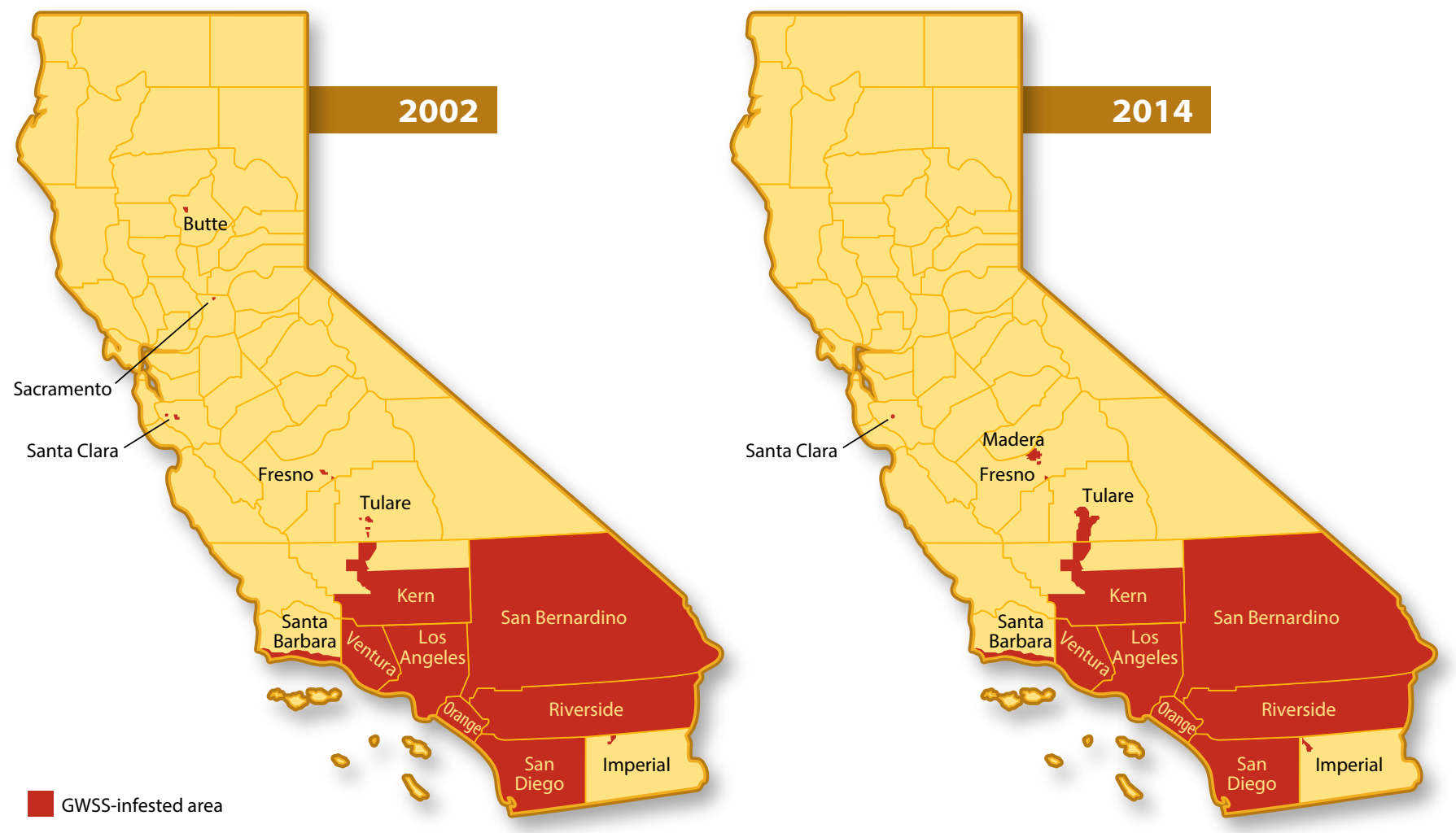

Fig. 1. Areas of California infested by GWSS in 2002 and 2014. At the end of 2002, GWSS was confined mostly to Southern California counties, with minor infestations in three Northern California counties. The Southern California infestation in 2014 is slightly expanded compared to the infestation in 2002, but some Northern California infestations have been eradicated. Other infestation maps are available at cdfa.ca.gov/pdcp/map_index.html. 
transgenes capable of interfering with $X$. fastidiosa infection of grapevine or the mechanisms on which they might operate. Infecting $X$. fastidiosa bacterial cells reside not in the living cells of the plant, where a transgene product normally would accumulate, but in the xylem, the array of dead cells that form the vascular elements responsible for conducting water and minerals from the roots into the aerial parts of the plant. Responding to this challenge, researchers not only identified various genetic elements that encode molecules that restrain the accumulation and/or spread of $X$. fastidiosa but also elements that deliver these molecules to the xylem. Importantly, several of the molecules were shown to cross graft unions and to confer, as a transgenic rootstock, protection to a grafted nontransgenic scion. Rootstock-conferred resistance has obvious versatility: Varietal scions now in use could be grafted onto the transgenic rootstock line and be at least partially protected against $X$. fastidiosa.

The transformed lines that have been examined closely are indistinguishable from the untransformed lines from which they were derived (Dandekar et al. 2011; Lindow et al. 2014), suggesting that the vines have the quality and horticultural traits of the untransformed lines. This result is expected because the transformation process introduces only a minute change in the plant genome. In commercialization, combinations of several transgenes acting through distinct biochemical mechanisms of action likely would be introduced into a grapevine line to obtain at least additive resistance effects and to greatly reduce the chance that a variant $X$. fastidiosa would be able to overcome resistance. The following paragraphs summarize five mechanistically diverse and clever experimental approaches for developing transgenic resistance to $X$. fastidiosa in grapevines.

Fusion of two proteins. One straightforward approach to reducing the titer of $X$. fastidiosa in grapevine xylem is to discover or develop a protein capable of killing or preventing the increase of $X$. fastidiosa cells and then to deliver that protein to the xylem. A research group headed by Abhaya Dandekar at UC Davis and including Goutam Gupta of Los Alamos National Laboratory conceived the approach of fusing two proteins, each with some activity against $X$. fastidiosa, into a single, xylem-targeted protein. One protein of the fusion pair binds to a specific protein that is abundant on the surface of the $X$. fastidiosa cell. The other protein breaches the $X$. fastidiosa cell membrane, thereby killing the bacterial cell. Both proteins killed X. fastidiosa cells

\section{Coordinated response to PD involves growers, scientists and government}

$$
\text { he }
$$

he academic and government research on GWSS and PD

received support from the state's viticulture and enology industries and even local government before and during the Temecula Valley outbreak. Industry organizations partnering with CDFA and UC Division of Agriculture and Natural Resources (UC ANR) in these efforts included the American Vineyard Foundation, the California Table Grape Commission, the California Raisin Board and the California Rootstock Commission. UC ANR and CDFA provided


ordination to prioritize research, void duplication and maximize the collective benefits of the programs. Since 1999, USDA has provided about $75 \%$ of the funding for PD control and research, and the state of California, industry and UC have provided the rest. California legislation initiated a statewide assessment on wine grapes to support research and related activities, raising about $\$ 46$ million to date (Tumber et al. 2014; Wiggins 2001). The timeline here highlights some of the key events in the efforts to contain and find solutions to the PD outbreak in California.

\section{6}

UC ANR forms Viticulture Consortium (VC), funded by a grant from USDA Cooperative State Research, Education, and Extension Service (USDA CSREES, now USDA NIFA, National Institute of Food and Agriculture).

Report of GWSS establishment in Southern California is published.

1997

Industry-matched state funds initiate the California Competitive Grant Program for Research in Viticulture and Enology (CCGPRVE).

1998

Search for biological control agents for GWSS begins. 1999

Temecula Valley vineyards show severe damage from PD; GWSS is recognized as the vector.

Riverside County declares emergency; the county and city of Temecula each contribute $\$ 125,000$ for research.

UC appoints Pierce's Disease Research and Emergency Response Task Force to identify strategies for combating PD.

CDFA appoints task force with members from UC, California State University, CDFA, county agricultural commissioners, USDA and industry to identify PD/GWSS research priorities.

CA Assembly Bill 1232 provides $\$ 2.25$ million over 3 years to be matched by $\$ 0.75$ million in industry funds for PD/GWSS research; the CDFA competitive grants program is funded. 
in culture, but the fusion protein was significantly more potent than either protein component alone. Grapevines expressing the fusion protein showed significant protection against PD (Dandekar, Gouran et al. 2012).

HxfA protein. Bruce Kirkpatrick's laboratory at UC Davis identified a protein of X. fastidiosa, HxfA, which, when inactivated, surprisingly led to increased virulence of the bacterium (Guilhabert and Kirkpatrick 2005). This result suggests that, when active, HxfA suppresses virulence. Perhaps a grapevine line that produces HxfA could reduce PD severity by decreasing the virulence of infecting $X$. fastidiosa, and infecting $X$. fastidiosa would be less successful at inducing PD than in unaltered vines. Grapevine plants producing full-length or truncated versions of HxfA were constructed. The genes were designed to cause the HxfA protein to be secreted into the xylem, where infecting $X$. fastidiosa cells colonize the vine. Greenhouse-grown plants were found to have reduced disease symptoms compared to unaltered grapevines when inoculated with a high dose of $X$. fastidiosa (Kirkpatrick et al. 2012).

XfDSF, pathogen confusion. Steven

Lindow and his research associates at UC Berkeley intensely investigated intercellular communication of $X$. fastidiosa and applied their findings to suppress the spread of the bacterium in the plant using a phenomenon they refer to as pathogen confusion. X. fastidiosa secretes a specific 14-carbon fatty acid and possibly other similar molecules as diffusible signal factors (XfDSF). As X. fastidiosa populations grow, the concentration of XfDSF around the cells increases. Compared to the unaltered bacterium, X. fastidiosa mutants that fail to produce XfDSF spread more readily in the plant, whereas spread of mutants that overproduce XfDSF is severely restricted (Chatterjee et al. 2008).

Transfer of a gene whose product catalyzes XfDSF synthesis should result in accumulation of XfDSF even in the absence of X. fastidiosa and, after inoculation with $X$. fastidiosa, should constrain movement and accumulation of $X$. fastidiosa and reduce PD symptom extent and intensity. These expected results have been observed (Lindow et al. 2012, 2014).

Programmed cell death. The characteristic scorching symptoms of PD were shown by the laboratory of David Gilchrist at UC Davis to be an example of the phenomenon known as genetically programmed cell death, where the symptoms resulted from a reaction of the plant to the presence of a bacterium (X. fastidi$o s a)$ rather than directly to an action of that bacterium (Gilchrist et al. 2007). This
2000

UC is awarded USDA CSREES grant of $\$ 2$ million to establish a competitive grants program for PD/GWSS research; annual funding was renewed eight times.

UC establishes Pierce's Disease Competitive Grants Program.

CA Senate Bill 671 provides funds for a coordinated statewide effort against PD/GWSS.

Federal government declares emergency and provides $\$ 22.3$ million for GWSS containment and PD research.

First GWSS infestation is found outside the generally infested Southern California area, in Contra Costa County; eradication efforts begin.

CDFA adopts emergency regulations to prevent spread of GWSS on shipments of nursery stock, bulk grapes and (later) citrus.

2001

CA Assembly Bill 1394 creates the Pierce's Disease and GlassyWinged Sharpshooter Board and an assessment on wine grapes to fund PD/GWSS research and related activities; this assessment raised \$46 million through February 2014.

First area-wide management program begins in Kern County, testing methods for controlling PD and GWSS in large and diverse agricultural areas.

First annual PD/GWSS research symposium takes place.

\section{2}

GWSS infestation found in Contra Costa County in 2000 is declared eradicated, marking the first successful eradication of a localized GWSS infestation.

\section{4}

CDFA and UC competitive PD/GWSS research programs combine their proposal review processes.

CDFA-requested report "California Agricultural Research Priorities: Pierce's Disease" is published by National Research Council of the National Academies.

Number of GWSS biological control agents released in California since 1999 exceeds 1 million.

\section{5}

California wine grape growers vote to continue statewide PD/ GWSS wine grape assessment.

\section{8}

Nursery Stock Approved Treatment Protocol established to reduce need for GWSS inspections.

\section{0}

California wine grape growers vote again to continue statewide PD/GWSS wine grape assessment, with option to support research and outreach on other wine grape pests and diseases.

2011

Last CCGPRVE-supported project completed, and the program ends.

\section{3}

Last projects funded by USDA-UC and VC are completed; these programs end.

Industry-funded CDFA competitive grants program continues, with its proposal review process now conducted under UC ANR's Unified Grant Management for Viticulture and Enology. CA 




UC Davis plant scientist Abhaya Dandekar and colleagues have fused two genes to engineer resistance to Pierce's disease of grapevines.

\section{Varietal scions now in use could be grafted onto the transgenic rootstock line and be at least partially protected against $X$. fastidiosa.}

protection against $X$. fastidiosa. Protection and level of PGIP accumulation were positively correlated in different transformed grapevine lines (Aguero et al. 2005). PGIP is naturally targeted to the xylem, and PGIPgenerating rootstocks protected grafted nontransgenic scions. The untransformed

research group searched a large collection of grapevine genes for the ability of specific nucleotide sequences to confer protection against programmed cell death in tomato roots. Two of these grapevine nucleotide sequences, when transferred back into grapevine, suppressed PD symptoms and prevented death of the X. fastidiosainoculated plants (Harvey et al. 2008). Moreover, the bacterial titer was reduced by 4 to 6 orders of magnitude relative to the titer in untransformed control vines, which died in 2 to 3 months. In the transformed plants, $X$. fastidiosa titers were reduced to a level that should result in only rare or no acquisition by the sharpshooter. One of the nucleotide sequences, when introduced into the rootstock only, was able to protect untransformed scions (Gilchrist and Lincoln 2009).

PG-inhibiting protein (PGIP). The $X$. fastidiosa genome has one gene for the enzyme polygalacturonase (PG), an enzyme that cleaves homogalacturonan, a major component of the intercellular matrix that joins the walls of adjacent plant cells. A X. fastidiosa strain with an inactive PG was unable to move long distance in the inoculated plant or to induce PD symptoms (Roper et al. 2007). UC Davis researchers Abhaya Dandekar, John Labavitch and Ann Powell lead research groups that have demonstrated interference with $X$. fastidiosa accumulation in plants by the action of a PG-inhibiting protein (PGIP). The PGIP from pear fruit was found to be effective in inhibiting bacterial PG. The pear PGIP gene was moved into grapevine, where it provided scion was demonstrated to accumulate PGIP from its PGIP-transgenic rootstock, suggesting that transported PGIP is the actual agent of protection in the scion (Dandekar, Gilchrist et al. 2012; Labavitch et al. 2012).

Tests of transformed grapevine lines were performed first in the greenhouse, and outdoor trials of these newly developed grapevine materials were begun in March 2010. The field trials are expected to yield valuable information on the feasibility of developing these approaches into commercial applications (Gilchrist et al. 2012; Miller et al. 2012).

\section{Research advances}

The seriousness of the GWSS-borne $X$. fastidiosa threat to the California wine and grape industries was realized early in the Temecula Valley PD outbreak, and effective cooperation between federal, state and county agricultural agencies, industry groups, and UC followed. Actions taken to combat the Temecula Valley PD epidemic and prevent its spread were rapidly mounted, and funding from federal, state and industry sources has supported both control measures and basic and applied research. A summary of current research and control costs associated with PD appeared recently (Tumber et al. 2014), and the sidebar below indicates some of the research expenditures.

Of the biological actors in the epidemic (X. fastidiosa, GWSS and grapevine), none was regarded in 1999 as being well characterized in research terms, and all seemed at the time to be almost intractable in molecular terms. Over the years, research projects were supported at 16 universities and at several government laboratories, and the continued funding from various sources, including growervoted assessments (see sidebar, pages 138-9), resulted in numerous advances in our understanding of the biology of the disease and the development of effective control measures.

The entire genome sequence of $X$. fastidiosa became available, and procedures for creating mutants of the bacterium and introducing new genes were developed and applied (Guilhabert et al. 2001; Guilhabert and Kirkpatrick 2003; Newman et al. 2004; Van Sluys et al. 2003). Genetic variation in X. fastidiosa was characterized as to its origins and its determination of host range (Nunney 2011; Nunney et al. 2013). Individual events in the association of $X$. fastidiosa with the sharpshooter and the establishment of feeding sites by the sharpshooter have been revealed (Almeida and Purcell 2003; Almeida et al. 2005; Son et al. 2012). The arrays of grapevine messenger RNAs (responsible for directing the synthesis of proteins) that accumulate under various situations were characterized and revealed grapevine genes that specifically respond to $X$. fastidiosa infection but not to drought (Choi et al. 2010, 2013). In cold curing, X. fastidiosa was found to be cleared not by the effects of low temperatures alone but by the grapevine's response to the cold (Feil and Purcell 2001; Lieth et al. 2011). Obviously, these research advances would not have been possible without the sources of research support indicated above. The new discoveries have elevated the bacterium, the insect vector and the plant host close to the level of a model research system and created a foundation for new management strategies in the future. CA

G. Bruening, B.C. Kirkpatrick and R.K. Webster are all Professor Emeritus, Department of Plant Pathology, UC Davis; T. Esser is Special Assistant, Pierce's Disease Control Program, California Department of Food and Agriculture, Sacramento. 


\section{References}

Aguero CB, Uratsu SL, Greve C, et al. 2005. Evaluation of tolerance to Pierce's disease and Botrytis in transgenic plants of Vitis vinifera L. expressing the pear PGIP gene. Mol Plant Pathol 6(1):43-51. doi:10.1111/j.13643703.2004.00262.x

Almeida RPP, Purcell AH. 2003. Transmission of Xylella fastidiosa to grapevines by Homalodisca coagulata (Hemiptera:Cicadellidae). J Econ Entomol 96(2):264-71. doi:10.1603/0022-0493-96.2.264

Almeida RPP, Wistrom C, Hill BL, et al. 2005. Vector transmission of Xylella fastidiosa to dormant grape. Plant Dis 89(4):419-24. doi:10.1094/pd-89-0419.

Anas O, Harrison UJ, Brannen PM, et al. 2008. The effect of warming winter temperature on the severity of Pierce's disease in the Appalachian mountains and Piedmont of the southeastern United States. Plant Health Progress. www.plantmanagementnetworkorg/pub/php/ research/2008/pierces. doi:101094/PHP-2008-0718-01-RS. Andersen PC, Brodbeck BV, Mizell RF. 2003. Plant and insect characteristics in response to increasing density of Homalodisca coagulata on three host species: A quantification of assimilate extraction. Entomologia Experimentalis Et Applicata 107(1):57-68. doi:10.1046/ j.1570-7458.2003.00036.x.

[CDFA] California Department of Food and Agriculture 2001. Pierce's Disease Control Program, Report to the Legislature, January 1, 2001 (2000 Report). www.cdfa. ca.gov/pdcp/ReportsToLegislature.html. 33 p plus appendices.

CDFA. 2005. Pierce's Disease Control Program, Report to the Legislature, April 2005 (2004 Report). www.cdfa. ca.gov/pdcp/ReportsToLegislature.html. 28 p plus appendices.

CDFA. 2013. Pierce's Disease Control Program, Report to the Legislature (2012 Report). www.cdfa.ca.gov/pdcp/ ReportsToLegislature.html, www.cdfa.ca.gov/pdcp/ map_index.html. 24 p.

Chatterjee S, Wistrom C, Lindow SE. 2008. A cell-cell signaling sensor is required for virulence and insect transmission of Xylella fastidiosa. P Natl Acad Sci USA 105:2670-5.

Choi HK, da Silva FG, Lim HJ, et al. 2010. Diagnosis of Pierce's disease using biomarkers specific to Xylella fastidiosa rRNA and Vitis vinifera gene expression. Phytopathology 100(10):1089-99. doi:10.1094/phyto-01-10-0014.

Choi HK, landolino A, da Silva FG, et al. 2013. Water deficit modulates the response of Vitis vinifera to the Pierce's disease pathogen Xylella fastidiosa. Mol Plant Microbe In 26(6):643-57. doi:10.1094/mpmi-09-12-0217-r. Dandekar AM, Gilchrist D, Miller T, et al. 2012. Chimeric antimicrobial protein and polygalacturonase-inhibiting protein transgenic grapevine field trial. In: Esser T (ed.). Pierce's Disease Research Progress Reports. Sacramento: California Department of Food and Agriculture. p 94-103. www.cdfa.ca.gov/pdcp/research.html.

Dandekar AM, Gilchrist D, Miller T, et al. 2011. Chimeric antimicrobial protein and polygalacturonase-inhibiting protein transgenic grapevines field trial. In: Esser T (ed.). Pierce's Disease Research Progress Reports. Sacramento: California Department of Food and Agriculture. p 101-6. www.cdfa.ca.gov/pdcp/research.html.

Dandekar AM, Gouran H, Ibanez AM, et al. 2012. An engineered innate immune defense protects grapevines from Pierce disease. P Natl Acad Sci USA 109(10):3721-5. doi:10.1073/pnas.1116027109.

Daugherty MP, Almeida RPP. 2009. Estimating Xylella fastidiosa transmission parameters: Decoupling sharpshooter number and feeding period. Entomologia Experimentalis Et Applicata 132(1):84-92. doi:10.1111/ j.1570-7458.2009.00868.x

Davis MJ, Purcell AH, Thomson SV. 1978. Pierce's disease of grapevines - isolation of causal bacterium. Science 199(4324):75-7. doi:10.1126/science.199.4324.75.
Feil H, Feil WS, Purcell AH. 2003. Effects of date of inoculation on the within-plant movement of Xylella fastidiosa and persistence of Pierce's disease within field grapevines. Phytopathology 93(2):244-51. doi:10.1094/ phyto.2003.93.2.244

Feil H, Purcell AH. 2001. Temperature-dependent growth and survival of Xylella fastidiosa in vitro and in potted grapevines. Plant Dis 85(12):1230-4. doi:10.1094/ pdis.2001.85.12.1230

Gilchrist DG, Lincoln JE. 2009. Systemic control of Pierce's disease by altered expression of anti-apoptotic genes or their RNA-based regulatory elements. In: Esser T (ed.) Pierce's Disease Research Symposium. CDFA, Sacramento. p 10-11. www.cdfa.ca.gov/pdcp/research.html.

Gilchrist DG, Lincoln JE, Cook DR. 2007. Resistance to Pierce's disease by transgenic expression of plant-derived anti-apoptotic genes. In: Esser T (ed.). Pierce's Disease Research Symposium. CDFA, Sacramento, CA. p 252-5. Gilchrist D, Lincoln J, Kominek T, et al. 2012. Field evaluation of grape plants expressing potential protective DNA sequences effective against Pierce's disease. In: Esser T (ed.). Pierce's Disease Research Progress Reports. CDFA Sacramento. p 109-11. www.cdfa.ca.gov/pdcp/research html.

Grafton-Cardwell EE, Reagan CA, Ouyang Y. 2003. Insecticide treatments disinfest nursery citrus of glassy-winged sharpshooter. Calif Agri 57(4):128-31.

Guilhabert MR, Hoffman LM, Mills DA, et al. 2001. Transposon mutagenesis of Xylella fastidiosa by electroporation of Tn5 synaptic complexes. Mol Plant Microbe In 14(6):701-6.

Guilhabert MR, Kirkpatrick BC. 2003. Transformation of Xylella fastidiosa with broad host range RSF1010 derivative plasmids. Mol Plant Pathol 4(4):279-85. doi:10.1046/ j.1364-3703.2003.00175.x.

Guilhabert MR, Kirkpatrick BC. 2005. Identification of Xylella fastidiosa antivirulence genes: Hemagglutinin adhesins contribute to $X$. fastidiosa biofilm maturation and colonization and attenuate virulence. Mol Plant Microbe In 18(8):856-68.

Harvey JJW, Lincoln JE, Gilchrist DG. 2008. Programmed cell death suppression in transformed plant tissue by tomato cDNAs identified from an Agrobacterium rhizogenes-based functional screen. Mol Genet Genomics 279(5):509-21. doi:10.1007/s00438-008-0329-2.

Hopkins DL, Purcell AH. 2002. Xylella fastidiosa: Cause of Pierce's disease of grapevine and other emergent diseases. Plant Dis 86(10):1056-66. doi:10.1094/ pdis.2002.86.10.1056.

Kabashima J, Gutman G, Redak R, et al. 2011. GWSS Nursery Approved Treatment Best Management Practices. CDFA. 23 p.

Kirkpatrick BC, Lincoln JE, Roper C, et al, 2012. Evaluation of Pierce's disease resistance in transgenic Vitis vinifera grapevines expressing either grape thaumatin-like protein or Xylella fastidiosa hemagglutinin protein. In: Esser $T$ (ed.). Pierce's Disease Research Symposium. CDFA, Sacramento. p 130-6.

Labavitch JM, Powell ALT, Bennett A, et al. 2012. Optimiz ing grape rootstock production and export of inhibitors of Xylella fastidiosa polygalacturonase activity. In: Esser T (ed.). Pierce's Disease Research Symposium. CDFA, Sacramento. p 147-53.

Lieth JH, Meyer MM, Yeo K-H, et al. 2011. Modeling cold curing of Pierce's disease in Vitis vinifera'Pinot Noir' and 'Cabernet Sauvignon' grapevines in California. Phytopathology 101:1492-500

Lindow SE, lonescu M, Baccari C, et al. 2012. Enhancing control of Pierce's disease by augmenting pathogen signal molecules. In: Esser T (ed.). Pierce's Disease Research Progress Reports. CDFA, Sacramento. p 154-66. www. cdfa.ca.gov/pdcp/research.html.

Lindow S, Newman K, Chatterjee S, et al. 2014. Production of Xylella fastidiosa diffusible signal factor in transgenic grape causes pathogen confusion and reduction in severity of Pierce's disease. Mol Plant Microbe In 27(3):244-54. doi:10.1094/mpmi-07-13-0197-fi.
Miller T, Daugherty M, Mauk P. 2012. Field trial for resistance to Pierce's disease. In: Esser T (ed.). Pierce's Disease Research Progress Reports. CDFA, Sacramento. p 175-7. www.cdfa.ca.gov/pdcp/research.html.

Newman KL, Almeida RPP, Purcell AH, et al. 2004. Cell-cell signaling controls Xylella fastidiosa interactions with both insects and plants. P Natl Acad Sci USA 101(6):1737-42.

Nunney L. 2011. Homologous recombination and the invasion of a new plant host by the pathogenic bacterium, Xylella fastidiosa. Phytopathology 101(6):S130.

Nunney L, Vickerman DB, Bromley RE, et al. 2013. Recent evolutionary radiation and host plant specialization in the Xylella fastidiosa subspecies native to the United States. Appl Environ Microb 79(7):2189-200. doi:10.1128/ aem.03208-12

Purcell A, Finley AH. 1979. Evidence for noncirculative transmission of Pierce's disease bacterium by sharpshooter leafhoppers. Phytopathology 69:393-5

Purcell AH, Saunders SR. 1999. Fate of Pierce's disease strains of Xylella fastidiosa in common riparian plants in California. Plant Dis 83(9):825-30.

Redak R, Bethke J. 2003. Toward a standardized treatment protocol to eliminate glassy-winged sharpshooter egg masses in commercial nursery stock. In: Esser T (ed.). Pierce's Disease Research Symposium. CDFA, Sacramento. p 308-10.

Redak RA, Purcell AH, Lopes JRS, et al. 2004. The biology of xylem fluid-feeding insect vectors of Xylella fastidiosa and their relation to disease epidemiology. Annu Rev Entomol 49:243-70. doi:10.1146/annurev. ento.49.061802.123403.

Roper MC, Greve LC, Warren JG, et al. 2007. Xylella fastidiosa requires polygalacturonase for colonization and pathogenicity in Vitis vinifera grapevines. Mol Plant Microbe In 20(4):411-9. doi:10.1094/mpmi-20-4-0411.

Son Y, Backus EA, Groves RL, et al. 2012. Pattern of stylet penetration activity by Homalodisca vitripennis (Hemiptera: Cicadellidae) adults in relation to environmental temperature and light conditions. Environ Entomol 41(5):1215-30. doi:10.1603/en11319.

Triapitsyn SV, Mizell RF, Bossart JL, et al. 1998. Egg parasitoids of Homalodisca coagulata (Homoptera: Cicadellidae). Fla Entomol 81:241-3.

Tumber KP, Alston JM, Fuller KB. 2014. Pierce's disease costs California \$104 million per year. Calif Agr 68(12):20-9.

Van Sluys MA, de Oliveira MC, Monteiro-Vitorello CB, et al. 2003. Comparative analyses of the complete genome sequences of Pierce's disease and citrus variegated chlorosis strains of Xylella fastidiosa. J Bacteriol 185(3):1018-26. doi:10.1128/jb.185.3.1018-1026.2003.

Varela LG, Smith RJ, Phillips PA, et al. 2001. Pierce's Disease. UC ANR Pub 21600. Oakland, CA. p 20.

Viana AP, Riaz S, Walker MA. 2011. Evaluating genetic diversity and optimizing parental selections in a segregating table-grape population. Am J Enol Viticult 62(3):285-90. doi:10.5344/ajev.2011.10073.

Walker A, Riaz S. 2012. Genetic mapping of Xylella fastidiosa resistance gene(s) in grape germplasm from southern United States. In: Esser T (ed.). Pierce's Disease Research Symposium. CDFA, Sacramento. p 241-7. Walker A, Tenscher A. 2012. Breeding to Pierce's disease resistant winegrapes. In: Esser T (ed.). Pierce's Disease Research Symposium. CDFA, Sacramento. p 233-40. Weare BC. 2009. How will changes in global climate influence California? Calif Agri 63(2):59-66.

Webster RK, Nation SP. 2000. Report of the University of California Pierce's Disease Research and Emergency Response Task Force. UC Office of the President. 62 p. Wiggins P. 2001. Food and Agriculture Code, Amend. California State Assembly Bill 1394. Pests: Pierce's disease and the Glassy-winged Sharpshooter. http://www.leginfo. ca.gov/pub/01-02/bill/asm/ab_1351-1400/ab_1394 bill_20010725_chaptered.html. 